\title{
FENNTARTHATHATÓSÁG: KUDARC ÉS KIÚT KORUNK NAGY KÉRDÉSE ÉS EGY LEHETSÉGES VÁLASZ
}

\author{
Lengyel Attila ${ }^{1}$
}

1 Turizmus vendéglátás Tanszék, Gazdálkodási Kar, Neumann János Egyetem, Magyarország

\author{
Kulcsszavak: \\ fenntarthatóság, tétlenség, világszemlélet, paradigmaváltás
}

\section{Keywords:}

sustainability, inaction, world view, mindfulness, paradigm change

\section{Összefoglalás}

Az elmúlt évtizedek fenntarthatóság érdekében tett eröfeszítései globálisan kudarcosak. Még mindig a legrosszabb klímaforgatókönyv szerint haladunk, a sokak által történelmi mérföldkönek nevezett párizsi klamacsúcs nem hozott valódi áttörést. A tétlenségre számos magyarázat született. Arra már kevesebb, hogy miként lehetne az emberekben valódi szemléletváltást elérni.

\section{Abstract}

Global sustainability efforts of the past decades have been unsuccessful. Humanity is still on track to worst-case climate scenario, the Paris Climate Conference, labeled as historic by many, did not prove to be a real breakthrough. Several explanations have been proposed to account for inaction. Few, however, have addressed the question of how a change in world view could be induced in people.

\section{Bevezetés}

A „Növekedés határai” c. alapmű megjelenése óta eltelt közel fél évszázadban sokan sokféleképpen próbálták már felhívni a figyelmet a fenntarthatósággal kapcsolatos problémákra. A klímaváltozás tekintetében sikertelenül. Az 1. ábrán a tengerfelszín felett mért szén-dioxid koncentráció változását láthatjuk a COP klímakonferenciák éveiben.

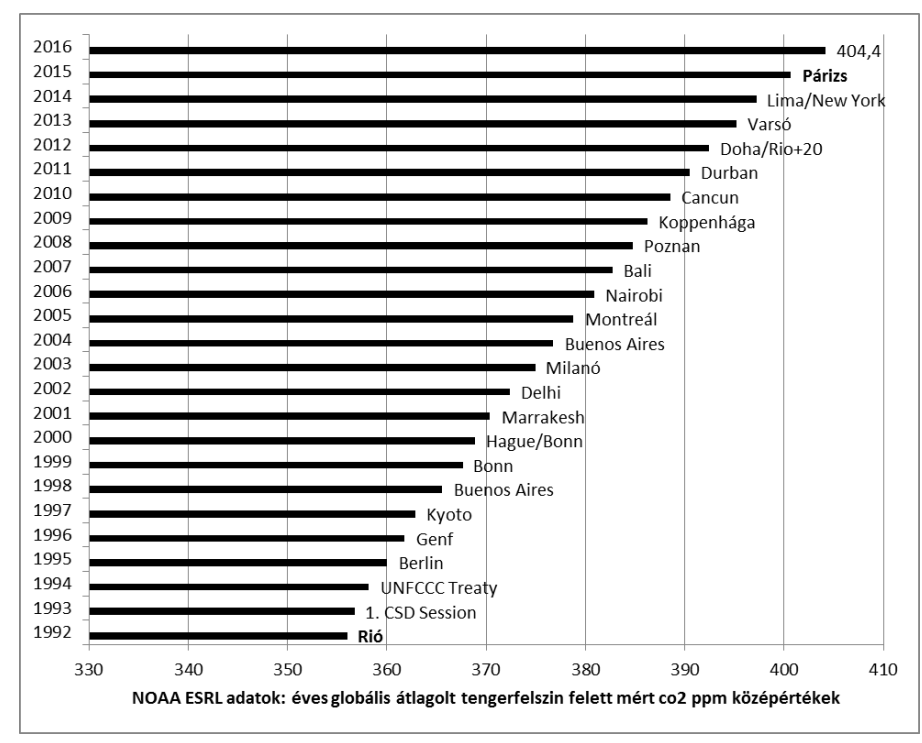

1. ábra. CO2 koncentráció változás a COP klímakonferenciák éveiben 
A NOAA előrejelzései szerint 2017-ben a 410 ppm érték sem kizárt, az emisszió növekedése folyamatos.

A politikusok által történelminek, egyes médiumok által az eddigi legnagyobb diplomáciai sikernek nevezett párizsi COP21 nem jelent tényleges fordulópontot. Maga az ENSZ mutat rá, hogy a jelenlegi INDCs (Tervezett Nemzetileg Meghatározott Hozzájárulások) alapján legjobb esetben is jóval $3^{\circ} \mathrm{C}$ fölé menne az évszázad végére a hőmérséklet emelkedése, a klímakutatók által még menedzselhetőnek tartott $2{ }^{\circ} \mathrm{C}$ helyett. A vállalások jogilag nem számon kérhetők, semmiféle garancia nincs a betartásukra. Ha az ENSZ klíma konvenciójának "közös, de különböző mértékű felelősség" elve alapján vizsgáljuk az INDC-kat, akkor még kevésbé nevezhető áttörésnek a COP21 Párizsban. A cselekvési képességet és az eddigi kibocsátásból eredő felelősséget egyenlően súlyozva megállapított méltányos hozzájárulás (fair share) tekintetében az látható, hogy a történelmileg és jelenleg is nagy kibocsátók közül az USA és az EU a rá eső méltányos hányadnak az egy ötödét, Japán egytizedét vállalta. A gazdagabb országok összességében a méltányos rész 23 \%-át vállalták, míg a szegényebbek a 100\%-át [8]. A fejlődő országok 2007 óta összességében nagyobb emissziót produkálnak, mint a fejlett világ, de az 1850-óta számított kumulatív adatokat alapján a légkörben lévő szén-dioxid 60\%-áért az USA és az EU-25 országok a felelősek, a fejlett világ pedig összességében a jelenlegi szén-dioxid terhelésnek közel 80\%-át okozta.

Az igazságos megoldást az is nehezíti, hogy amíg a fejlett országok károsanyagkibocsátásának jelentős része életstílusból adódó szennyezés (lifestyle emission), addig a fejlődő országok emissziójából a nagyobb hányad az alapvető életfeltételek biztosításához kell (survival emission). Hogy mi az „alapvető”, az persze kérdéses. Valószínúleg egészen más választ adna egy luxemburgi és egy nigériai átlagember. A klímaváltozás önmagában is óriási kihívás, de egyéb súlyosbodó krízistünetek is jelzik a földi ökoszisztéma egyensúlyának felbomlását. Rockström és szerzőtársai 2009-ben rámutattak, hogy az emberiség a kilenc fontos planetáris határból (planetary boundary) már többet átlépett. 2015-ben Steffen, Rockström és más kutatók megerősítették és kiterjesztették a 2009-es tanulmány megállapításait. A genetikai diverzitás, foszfor és nitrogénciklusok tekintetében az egyértelmúen magas kockázatú, a klímaváltozás és földhasználat (land system change) vonatkozásában pedig a növekvő rizikójú, bizonytalan kimenetelü zónában vagyunk [13]. A fenntarthatóság környezeti pillére veszélyesen megrepedezett. Ugyanez igaz a társadalmi alapokra is. Kérdéses, hogy meddig tartható fent egy olyan globalizált fogyasztói kapitalista világrend, amelyben (az OXFAM által közölt adatok szerint) az emberek leggazdagabb 10\%-a birtokolja az összes javak közel 90\%-át, vagy még erőteljesebben szemléltetve a szakadékot, ahol a 62 leggazdagabb milliárdos annyi vagyonnal rendelkezik, mint a világ szegényebbik fele (3,7 milliárd ember) összesen. A Világgazdasági Fórum (WEF) Globális Kockázatok kiadványa 2012, 2013 és 2014-ben is első számú kockázatként jelölte meg a jövedelmi különbségeket.

A gazdaság, ami a fenntarthatóság harmadik pillére, a fogyasztói kapitalista társadalmakban az állandó növekedésre épül. A pusztuló ökoszisztémán kívül a 2008-as globális méretü válság is egyértelmúen jelezte, hogy ez nem lehetséges. Annak ellenére, hogy az utóbbi évtizedekben elméleti szinten már több GDP alternatíva is született (GPI, ISEW, GNH, HDI, LPI stb.), a fogyasztói kapitalista társadalmak még mindig a GDP bűvöletében élnek, ez a döntéshozatalt leginkább meghatározó tényező. A Globális Kockázatok jelentésben a hatásnagyság alapján 2007-2014 között minden évben a világgazdaság és pénzpiacok összeomlása szerepelt első számú kockázatként (WEF, 2016). Susan Strange angol közgazdász Kaszinó kapitalizmus c. könyvében már 1986-ban rávilágított arra, hogy a globális pénzügyi rendszer a kaszinókhoz hasonlóan sokféle hazardírozási lehetőséget kínál. Sajnos ebben a világméretű „kaszinóban” a játékosok nem csupán a saját pénzüket teszik kockára. J. Stiglitz és más neves közgazdászok a gigantikusra duzzadt globális adósságállomány átstrukturálását javasolják és a WEF-hez hasonlóan figyelmeztetnek a jövedelmi szakadék fenntarthatatlanságára. Mindhárom területen sokasodnak a figyelmeztető jelek.

\section{A tétlenség okai}

Az előzőekben taglalt problémákat figyelembe véve egyáltalán nem meglepő és még mindig időszerű Lányi András néhány éve megfogalmazott kérdése: „Hogyan lehetséges az, hogy egy mindenki által ismert, feltartóztathatatlanul közeledő katasztrófa elhárítása érdekében 
gyakorlatilag semmi sem történik?” [9]. Lányi ezt korunk nagy kérdésének nevezi. Diamond, Gifford és más társadalomtudósok számos magyarázattal szolgálnak arra nézve, hogy az egyén és az emberi közösségek miért nem akarnak vagy képesek olyan irányba változni, hogy egy közelgő katasztrófát elhárítsanak [4], [7]. Torz világszemlélet, lopakodó normalitás, elfojtás, bizalomhiány, tömegpszichózis, rendszer inercia (status quo), közlegelők tragédiája, rettegéskezelés elmélet, vallásos meggyőződés, vaklárma effektus, a természettel való összekapcsoltság hiánya vagy a problémák, a felelősség, az értékek időbeli és térbeli diszkontálása, néhány a lehetséges és sokszor egymást kiegészítő magyarázatok közül.

Terjedelmi okokból négyet emelnék ki ezek közül. A Diamond által is taglalt vaklárma hatás és lopakodó normalitás jelentős negatív tényező. Egymással átfedésben lévő jelenségekről van szó, amit a klímaváltozáson keresztül egyszerü megérteni. A klímaváltozás és az ökoszisztémát fenyegető egyéb problémák kapcsán az elmúlt évtizedekben sokan fogalmaztak meg vészjósló előrejelzéseket. Az átlagember látszólag jogosan gondolhatja: lám-lám a klíma még mindig elviselhető és az ökoszisztéma sem omlott össze. A melegedés lassan zajlik, hozzászokunk, ahogyan Diamond példájában a Montana-i emberek a hegyek hótakarójának eltünéséhez. A két jelenség a Google Trends segítségével globális léptékben is tetten érhető, ha megvizsgáljuk, hogyan változott a tipikus krízisterületek keresési kifejezéseinek keresési népszerüsége az elmúlt 12 évben. Az ecological problems (ökológiai problémák) keresési népszerúsége 2004 óta folyamatosan csökken. A global warming (globális felmelegedés) kifejezés keresési intenzitása 2004-2007 között nőtt, azóta folyamatosan csökken. A climate change (klímaváltozás) kifejezés esetében a 2004-es 90 körüli intenzitási érték (100 a maximum) 2008-ra 20 körülire esett, azóta pedig két 2010-es kiugró érték kivételével a 15-20 intenzitási sávban stagnál. Az energy crisis (energiaválság) esetében egy rövid 2008-as kiugrás kivételével az érdeklődés folyamatosan csökken. Az air pollution (légszennyezés) kifejezés népszerüsége 2004-2010 között folyamatosan csökkent, azóta stagnál. Ugyanez a helyzet a water pollution (vízszennyezés), deforestation (erdőírtás), desertification (sivatagosodás), ozon hole (ózon lyuk) és overpopulation (túlnépesedés) kifejezések esetében is. Annak ellenére, hogy ezeken a területeken fokozatosan romlott a helyzet az elmúlt tizenkét évben, az irántuk mutatott internetes érdeklődés vagy folyamatosan csökkent, vagy kezdeti csökkenés után stagnál. Jelentős hátráltató tényező a bizalomhiány. Az elkövetkezendő évtizedekben elkerülhetetlenek lehetnek olyan nem fogyasztóbarát döntések (negatív externáliák erőteljesebb adóztatása, ökoszisztéma szolgáltatások beárazása, fosszilis tüzelőanyagok állami támogatásának leépítése stb.), melyeket csak akkor lehet sikeresen végigvinni, ha az emberek megbíznak a döntéshozókban, politikusokban, közintézményekben, egymásban. A YouGov a Brexit kapcsán mérte a közbizalmat. A 2016-os felmérése szerint a britek több mint 70\%-a nem bízik a brit politikusokban, 74\%-uk az újságírókban, $37 \%$-uk a tudományos élet képviselőiben, 61\%-uk a vallási vezetőkben. Az Eurobarometer 2015-ös felmérése szerint a magyarok 62\%-a nem bízik a kormányban, 65\%-uk a parlamentben. Az USA-ban, amely a második legnagyobb üvegházgáz (GHG) kibocsátó jelenleg, a Gallup 2016-os felmérése szerint az emberek több mint 60\%-a kevéssé, vagy egyáltalán nem bízik a legfelsőbb bíróságban, a bankokban, az elnökben. Több mint 70\%-uk az igazságszolgáltatásban, újságokban, a tv- híradásban és több mint 80\%-uk a kongresszusban és a nagy cégekben. 1973 óta ezeken a területeken közel 50\%-kal esett vissza a bizalom az amerikai társadalomban [6]. Az Edelman Trust Barometer Trust Index-e (Bizalmi Index) az emberek kormányba, cégekbe, médiába és civil szervezetekbe (NGO) vetett bizalmát átlagolja. Ez alapján 2016-ban a vizsgált 28 országból 17 a bizalmatlanok közé tartozik. Köztük a klímavédelem szempontjából jelentős olyan országok, mint Ausztrália, Japán, Oroszország, Németország [5]. A negyedik tényező a legfontosabb, ez a gyökere a többi problémának. F. Capra Fordulópont c. könyvében a jelen válságot világszemléleti, alapvetően paradigmaválságként írja le [3]. Mi jellemző erre a világszemléletre? A férfi princípium uralta modernitás a világot darabokra szedte, szó szerint és átvitt értelemben egyaránt. Weöres Sándor csodálatosan megfogalmazza ezt a „A Nő” c. versében: 


\author{
„A férfi - akár bölcs, vagy csizmavarga - \\ a világot dolgokká széthabarja \\ s míg zúg körötte az egy-örök áram, \\ cimkék között jár, mint egy patikában. \\ Hiában száll be földet és eget, \\ mindég semmiségen át üget, \\ mert hol egység van, részeket teremt, \\ és névvel illeti a végtelent.”
}

Besarab Nicolescu, a Transzdiszciplináris Charta megalkotója, a tudomány, kultúra és spiritualitás egyesítésének szószólója (egyébként elismert kvantumfizikus) ugyanerre hívja fel a figyelmet, amikor a modernitás válságának okát alapvetően a sokféle formában testet öltő szubjektumobjektum dualitásban jelöli meg [12]. Ha nem is lehet Lynn White több évtizede vitákat kavaró, a nyugati típusú keresztény világszemléletet az ökológiai válságért okoló cikkének minden pontjával egyetérteni, az bizonyos, hogy a keresztény világlátásra szintén jellemző a (végletekig vitt) dualitás. Ahogyan a fogyasztói paradigmára is. A fogyasztói mennyországban a vevő (szubjektum) boldogságának feltétele az árucikkek (objektum) megszerzése. A szerzés természetesen csak ideigóráig teremtheti meg az egység illúzióját, a kétség és vágyakozás gyorsan visszatér. Aztán a kínálati oldal megint elhiteti velünk (mi pedig magunkkal), hogy az újabb termékek, a még több fogyasztás talán mégis enyhítheti a szomjúságot. A rendszer létalapja a szeparáltság illúziójának sulykolása. A jó élet, a boldogság eszményét alapvetően meghatározó fogyasztói paradigma azért is ördögien ügyes találmány, mert a birtoklási vágyra, a mohóságra, az érzékek kielégítésére, az emberi psziché könnyen manipulálható oldalára építkezik.

\title{
3. Boldogság, fenntarthatóság és a nagy kérdés
}

Nem megkerülhető a felvetés, miszerint az élet minőségének a végső fokmérője az egyén elégedettségének, boldogságának a mértéke. Bármiféle haladás, ha mégoly szofisztikált tudományos teljesítmény van is mögötte, teljességgel irreleváns, ha a történések alanya, az ember, mindezen változásoktól nem lesz boldogabb, esetleg boldogtalanabb lesz. Boldogabbak vagyunk? Legalább „megéri” végveszélybe sodorni saját létalapunkat? A boldogság, ahogyan a fenntarthatóság is, társadalmi és kulturális kontextus függvényében értelmezhető. Nem mindegy, hogy milyen kritériumok alapján minősítünk valamit fenntarthatónak, vagy valakit boldognak. Amennyiben például az adott társadalom fenntarthatóságának legfontosabb kritériuma a természettel való összhang, a boldogságé pedig a hagyományok, értékek megőrzése és a sok szabadon, egymással eltöltött idő, akkor az olyan több tízezer éves „primitív” közösségek, mint a Busman, Kung San vagy Bunurong fenntarthatóbbak, boldogabbak, és az időtávot figyelembe véve jóval sikeresebbek, mint a modern fogyasztói társadalmak. Easterlin óta már sokan bizonyították, hogy a boldogság leginkább vizsgált hedonikus dimenziója is csak egy bizonyos pontig tágítható anyagi javak segítségével. A „taposómalom hatások” (treadmill effects) okozta szabadidő csökkenés az erodálódó táras kapcsolatok, társadalmi integritás és szolidaritás miatt a gazdagság növekedésével párhuzamosan, összességében csökkenhet is a boldogság szintje. Az 50-es években a britek több mint 50\% vallotta magát nagyon boldognak. A 2000-es évek derekán ez már csak 30\% körüli érték volt, miközben az átlagos anyagi jólét jelentősen nőtt. Ráadásul úgy tűnik a „fogyasztói boldogság" csak a fenntarthatóság rovására lehetséges. Az 1. táblázatban a 2015-ös HPI (Happy Planet Index) boldog életévek (happy life years) dimenziója alapján első tíz helyen rangsorolt ország, valamint azok ökológiai lábnyoma látható. 
1. táblázat. A HPI 10 legboldogabb országának ökológiai láb nyoma

\begin{tabular}{|l|l|l|l|l|l|l|l|l|l|l|}
\hline Ország & CH & IS & S & NO & NL & FI & AT & DK & CA & AU \\
\hline HPI rang & 1 & 2 & 3 & 4 & 5 & 6 & 7 & 8 & 9 & 10 \\
\hline & & & & & & & & & & \\
\hline $\begin{array}{l}\text { Ökológiai } \\
\text { lábnyom }\end{array}$ & 5,8 & 6,4 & 7,3 & 5,0 & 5,3 & 5,9 & 6,1 & 5,5 & 8,2 & 9,3 \\
\hline
\end{tabular}

A Global Footprint Network szerint jelenleg 1,7 gha (globális hektár) jut egy földlakóra. Ennek alapján a fenti fogyasztói kapitalista társadalmak olyan áron boldogok, hogy közben minimum annyi erőforrást használnak, mintha három földbolygónk lenne. Jorgen Randers a Limits to growth társszerzője egy vele készült riportban kijelenti, teljesen hiábavalóan dolgozott az elmúlt 40 évben a fenntarthatóságért, mivel saját hazájának (Norvégia) állampolgárai, akik a világon a leggazdagabbak közé tartoznak, még a mai kritikus helyzetben sem hajlandóak a rövid távú előnyeikről lemondani a jövő generációi érdekében. Lemondás nélkül pedig nem fog menni. Zsolnai László, a buddhista közgazdaságtan szakértője hangsúlyozza, hogy csak a ma elképesztő mértékben túlfogyasztó társadalmak vágyakat és ezen keresztül a fogyasztást érintő jelentős önkorlátozása (degrowth) vezethet egy fenntarthatóbb állapothoz [15].

Hogyan lehet elérni azt, hogy az állandóan bővülő fogyasztásra szocializált társadalmak tagjai önkéntesen korlátozzák azokat a vágyaikat, melyeket a fogyasztói gépezet kínálati oldala a kötelező profitéhség miatt mindeáron szeretne fenntartani? Hogyan lehet a fejlődő országok lakóit meggyőzni, hogy ne is akarják elérni a kapitalista fogyasztói álmot? Mi az, ami cserébe elég meggyőző ahhoz, hogy egy ilyen paradigmaváltást katalizáljon, ami rábír egy szerzésre szocializálódott embert, hogy engedje el azt, amit eddig mohón megragadott? Hogyan lehet elérni, hogy megváltozzon, fenntarthatóvá váljon az emberek világszemlélete, értékrendje és viselkedése? Véleményem szerint ez korunk nagy kérdése.

\section{Mindfulness, világszemléleti paradigmaváltás, spirituális növekedés}

Sok párhuzam vonható az egyén és a közösségek krízishelyzetekben mutatott viselkedése között. Ahogyan az egyén inkább pirulákat kér az orvostól, életmódváltás helyett, a fogyasztói társadalmakban még mindig tartja magát az illúzió, hogy a tudomány és a technika (a „pirula”) majd minden fenntarthatósággal kapcsolatos problémát megold, és élhetünk úgy mint eddig, business as usual. Ha a túlhajszolt, erőforrásait kimerítő egyén nem figyel oda a teste által küldött egyre intenzívebb figyelmeztetésekre, nem hajlandó szemléletet és ezen keresztül életmódot változtatni, akkor jön az „Atyai” pofon (gyomorlyukadás, infarktus stb.). A földi ökoszisztéma régóta küldi a vészjeleket és a fokozatos leromlás nem marad a végtelenségig fokozatos. Hirtelen összeomlás (state shift) következhet. Amilyen az egyén esetében egy infarktus. Külső világunk fenntarthatatlanságáért elsősorban belső világunk fenntarthatatlansága a felelős. Torz a világszemléletünk. Növekednünk kell, de nem kívül, hanem belül, spirituálisan. Miközben a külső növekedést (gazdasági, anyagi prioritások) hajszoljuk évszázadok óta, belül összezsugorodtunk, szorongunk. A WHO előrejelzései szerint a következő évtizedben a szorongásos, depresszív betegségcsoportok lesznek a vezető egészségügyi problémák a világon. A külső, az anyagi világban messzire jutottunk, a kozmoszt, a kavantumvilágot ostromoljuk. Ideje helyreállítani az egyensúlyt és elindulni befelé. Ez a spiritualitás lényege.

A belső utazásban segíthetnek a keleti meditatív technikák. A meditáció a nyugati világszemlélet dualitásában (ember-Isten, ember-természet, társadalomtudománytermészettudomány, feminin-maszkulin stb.) szétfeszülő ember számára kínálja az egységélmény 
az összekapcsoltság megtapasztalásának lehetőségét. A buddhista „üresség” (sunyata) koncepcióját sokan félreértik és valamiféle nihilisztikus semmivel azonosítják. Valójában azt jelenti, hogy semmi sem létezik önmagában, saját jogán, csupán a világ többi részével való interkonnektivitásban, interdependenciában. Azt is mondhatnánk a sunyata a tökéletes rendszerszemlélet. Paradoxnak tűnhet (pedig csak a kozmikus tréfa része), de a tudományos térben centrum pozíciót elfoglaló kvantumfizika az, mely a meditatív hagyományok hosszú ideje hangoztatott elveihez kísértetiesen hasonló megállapításokra jut. Például az összekapcsoltság vagy a tudat tekintetében. Einstein haláláig reménykedett a részben általa felfedezett (ERP paradoxon), nonlokalitást feltételező „entanglement” jelenségének a cáfolatában. Az egykori híres gondolatkísérletet mára számos gyakorlati teszt bizonyította. Két előzőleg összefonódott (entangled), majd szétválasztott részecske között azonnali kommunikáció lehetséges akár végtelen távolságból is. Menas Kafatos kvantumfizikus szerint nem az a fó kérdés, hogy az univerzum egy egységes szövet-e, hanem az, hogy az elme hogyan hozza létre a szeparáltság illúzióját. Planck, Wiegner és Schroedinger tudat primátusáról tett kijelentései után talán nem meglepő, hogy a kortárs fizikusok közül S.A Wolf az egész univerzumot betöltő tudatóceánról beszél, a multidimenzionális hyperspace elméletének egyik úttörője S-P. Sirag elméleti fizikus szerint pedig kozmikus értelemben véve ténylegesen csak egy tudat van, és igazából ez minden, ami van.

A meditáció a tudat megismerésének eszköze. Bizonyos fokig rokonítható a fenomenológiával. Szemben azonban a Husserl által „rigorózus tudomány”-nak nevezett fenomenológiai módszerrel, a meditáció nem a tudatban felmerülő fenomének akkurátus katalogizálását jelenti, hanem a formán túli ontológiai valóság megismerését. Felmerül a kényes kérdés, szüksége van-e a keresztény kultúrkörnek keleti meditatív technikákra és egyáltalán összeegyeztethető-e a meditáció a kereszténységgel. A mai krízisért nagy részben felelős fejlett világ kétezer éve keresztény kontextusban létezik. Így jutottunk a katasztrófa közelébe. Nyitottnak kell maradni minden olyan lehetőségre, mely az egyén szintjén olyan világszemléletbeli változást tud generálni, ami megteremti egy fenntarthatóbb (tehát nem túlfogyasztó) világ lehetőségét.

A meditáció és a vallások kapcsolatának mélyebb tárgyalása szétfeszítené ennek a cikknek a kereteit, ezért csak két példát idézek a két legnagyobb történelmi egyház képviselőinek álláspontjából. Egy református honlapon megjelent Prof. John Malan cikkének fordítása a keleti típusú meditációkról. Malan leszögezi, hogy a meditáció az „önmegváltás antikrisztusi formája” [10]. Egy másik weboldal Jálics Ferenc jezsuita atya „szemlélődő lelkigyakorlatát” hirdeti a híveknek és a gyakorlat leírásában így fogalmaz: „Ebben a lelkigyakorlatban nyugodni hagyjuk szellemi képességeinket, és csak észlelni igyekszünk azt, aki VAN.” [11]. Ez akár a belső szemlélődésre épülő keleti meditációs gyakorlatok (mindfulness) definíciója is lehetne. Egybecseng azzal az ószövetségi résszel, ahol Isten az égő csipkebokorban „Vagyok”-nak nevezi magát, valamint azzal is, amikor Jézus egyértelmúvé teszi, a végső valóságot magunkban lelhetjük fel: „Az Isten országa nem szemmel láthatólag jő el. Sem azt nem mondják: Ímé itt, vagy: Ímé amott van; mert ímé az Isten országa ti bennetek van.”. A belső valóságra figyelő keleti meditatív technikák „mindfulness” néven válnak egyre népszerübbé. Hangsúlyozandó, hogy ezek a gyakorlatok, bár a keleti meditatív hagyományban gyökereznek, vallás semleges, minden ideológiától mentes, egyszerű, tisztán empirikus eszközök. Több évtizedes klinikai vizsgálatok bizonyítják a pozitív hatásokat [1]. Ezeket és a fenntarthatóságot pozitívan befolyásoló kedvező mellékhatásokat szemlélteti a 2. ábra. 


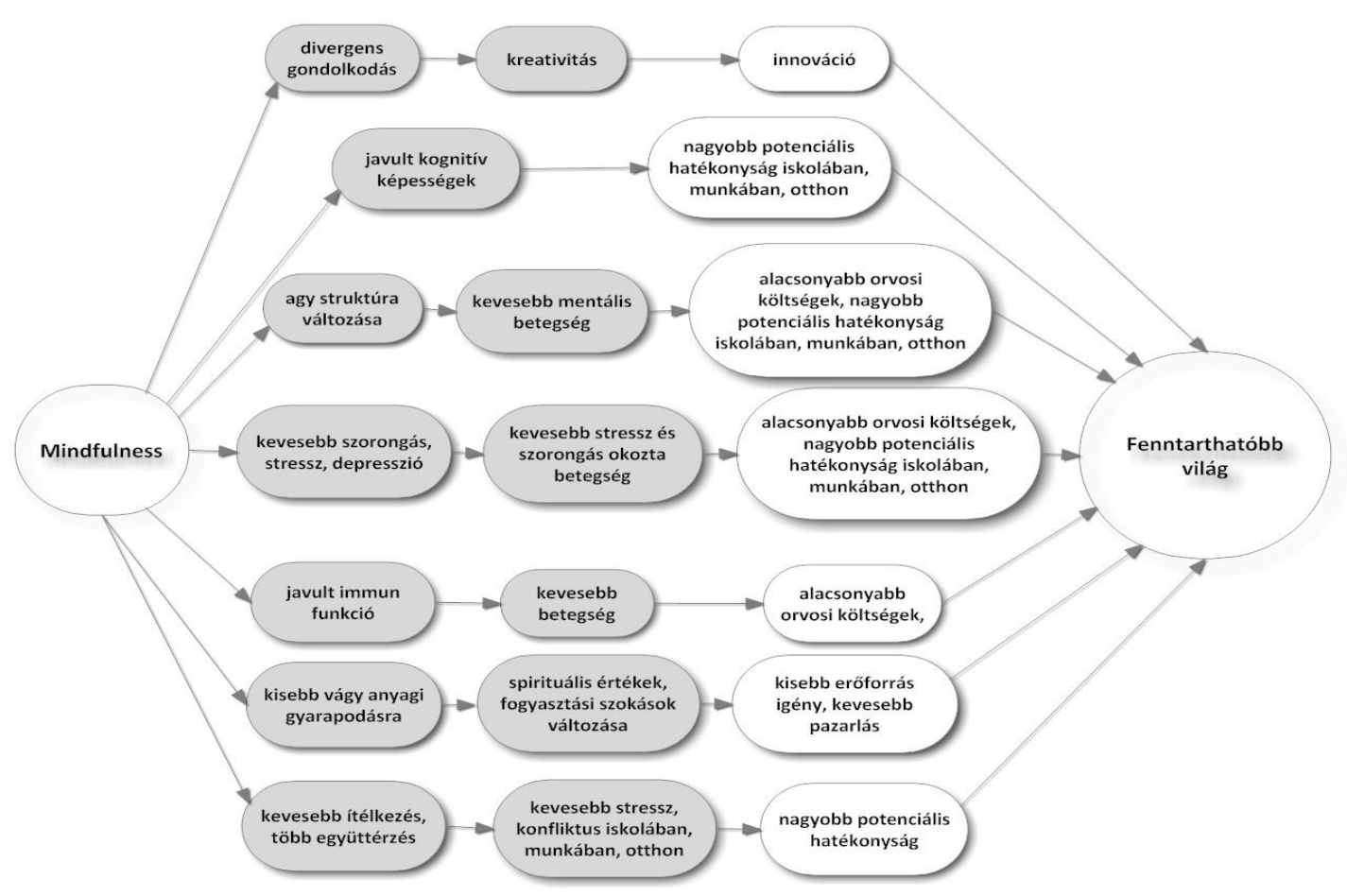

2. ábra. A mindfulness bizonyított hatásai és a fenntarthatóság szempontjából fontos lehetséges pozitív mellékhatásai

A fenntarthatóság szempontjából talán legfontosabb hozadék az, hogy a huzamosabb ideje meditálók fenntarthatóbb attitűdöt és magatartást mutatnak, kevésbé vannak kitéve a materiális dolgoktól való függőségnek [2]. A mindfulness-ben rejlő lehetőségeket és jelentőségét jól példázza a „Mindful Nation UK”. A több mint 40 oldalnyi összpárti munkacsoport által készített jelentésben ajánlásokat fogalmaznak meg arra vonatkozóan, hogyan lehetne a mindfulness képzést és tréningeket széles körben bevezetni, az Egyesült Királyság egészségügyi, oktatási, büntetésvégrehajtási intézményeiben, valamint a munkahelyeken általában [14].

A meditációs technikák iránti érdeklődés az utóbbi években töretlenül nő. A „meditation”, „meditate”, „yoga”, „mindful”, „mindfulness” alapszavakat is tartalmazó, meditáció témakörre jellemző több, mint száz tipikus angol kereső kifejezés Google Trends forgalmát vizsgálva az látszik, hogy 90\%-uk legalább az elmúlt három évben emelkedő keresési intenzitást mutat. Úgy tűnik, hogy az a fajta spirituális ébredés, mely meditatív technikákat hív segítségül az egyre sürgetőbb befelé forduláshoz, a legfelsőbb szintű politikai döntéshozatal (Mindful Nation UK) és a nagyközönség körében is zajlik. Azon túl, hogy ez örvendetes, egybevág azzal a fenntarthatóság kapcsán nyugvópontra jutott alapelvvel, miszerint a top-down és bottom-up erőfeszítések együttes hatása vezethet sikerre. A GDP helyett a GNH-t (Bruttó Nemzeti Boldogság) kidolgozó és bevezető Bhutan-ban a példaértékű fenntarthatósági erőfeszítések egyik fundamentuma a meditációs hagyomány. Talán nem meglepő, hogy a párizsi konferenciára előterjesztett INDC-k közül Bhutáné a legambiciózusabb. Bhután kis ország. Magyarország szintén az. Van remény. 


\section{Köszönetnyilvánítás}

Köszönettel tartozom a kutatás támogatásáért, amely az EFOP-3.6.1-16-2016-00oo6 „A kutatási potenciál fejlesztése és bővítése a Pallasz Athéné Egyetemen” pályázat keretében valósult meg. A projekt a Magyar Állam és az Európai Unió támogatásával, az Európai Szociális Alap társfinanszírozásával, a Széchenyi 2020 program keretében valósul meg.

\section{Acknowledgement}

This research is supported by EFOP-3.6.1-16-2016-00006 "The development and enhancement of the research potential at Pallasz Athéné University" project. The Project is supported by the Hungarian Government and co-financed by the European Social Fund.

\section{Irodalomjegyzék}

[1] Baer, Ruth A. (2003): Mindfulness training as a clinical intervention: A conceptual and empirical review. Clinical psychology: Science and practice, 10, 2, 125-143. WEBCÍM: http://www.personal.kent.edu/ dfresco/mindfulness/Baer_Mindfulness.pdf

[2] Brown, Kirk Warren - Kasser, Tim (2005): Are psychological and ecological well-being compatible? The role of values, mindfulness, and lifestyle. Social Indicators Research, 74., 349-368. WEBCÍM:

https://selfdeterminationtheory.org/SDT/documents/2005_BrownKasser_SIR.pdf

[3] Capra, Fritjof (1982): The Turning Point: Science. Society and the Rising Culture, Wildwood House, London.

[4] Diamond, Jarred (2005): Collapse: How societies choose to fail or succeed. Penguin.

[5] Edelman, (2016): Trust Barometer, Global results. WEBCíM: http://www.edelman.com/insights/intellectualproperty/2016-edelman-trust-barometer/global-results/

[6] GALLUP (2016): Confidence in Institutions. WEBCÍM: http://www.gallup.com/poll/1597/confidenceinstitutions.aspx

[7] Gifford, Robert (2011): The dragons of inaction: Psychological barriers that limit climate change mitigation and adaptation. American Psychologist, 66, 4, 290. WEBCÍM: http://www.ncbi.nlm.nih.gov/pubmed/21553954

[8] CivilSocietyReview (2015): Fair shares: a civil society equity review of indes. WEBCÍM:

http://civilsocietyreview.org/wp-content/uploads/2015/11/CSO_FullReport.pdf

[9] Lányi, András (2013): Morális klímaváltozás. Magyar tudomány. 7, 822-829. WEBCÍM:

http://www.matud.iif.hu/2013/o7/o7.htm

[10] Malan, John (2013): A keleti meditáció és a keresztyénség. WEBCÍM:

http://www.ujszeged.ref.hu/bongeszo/meditacio/

[11] Manréza (2011): Szemlélődő, Meditációs Lelkigyakorlat. WEBCÍM: http://manreza.hu/szemlelodo-meditacioslelkigyakorlat/

[12] Nicolescu, Besarab (2015): The Hidden Third and the Multiple Splendor of Being1. in Philosophy and science: Approaches, problems, prospects, 62. WEBCÍM: http://basarabnicolescu.fr/Docs_articles/TD_in_philosophy_Russia.pdf

[13] Steffen, Will - Richardson, Katherine - Rockström, Johan et al. (2015): Planetary boundaries: Guiding human development on a changing planet. Science, 6223. WEBCíM: http://science.sciencemag.org/content/347/6223/1259855

[14] The Mindfulness Initiative (2015): Mindful Nation UK. Report by the Mindfulness All-Party Parliamentary Group (MAPPG). WEBCÍM: http://themindfulnessinitiative.org.uk/images/reports/Mindfulness-APPG-Report_MindfulNation-UK_Oct2015.pdf

[15] Zsolnai,László (Ed.) (2015): The spiritual dimension of business ethics and sustainability management. New York: Springer. WEBCÍM: http://www.springer.com/us/book/9783319116761 